\title{
Upaya Membentuk Karakter Percaya Diri dan Kreatif Pada Anak Usia Dini Melalui Permainan Tradisional Jamuran
}

\author{
Mustakimah \\ PIAUD, Fakultas Ilmu Tarbiyah dan Keguruan, UIN Walisongo Semarang \\ mustakimah@walisongo.ac.id \\ Sri Mu'ammamah \\ PIAUD, Fakultas Ilmu Tarbiyah dan Keguruan, UIN Walisongo Semarang \\ amahamah43833@gmail.com
}

\begin{abstract}
The background of this research is the importance of forming good character in early childhood with the stimulation given to traditional mushroom play activities. The method used in this study is a qualitative research method. The purpose of this study is to describe how the traditional game of mold can shape the character of early childhood. Based on the results of traditional game research, molds can form characters in early childhood, including honest characters formed by the habit of children not lying when guessed by their friends, disciplined characters are formed by habituating children to follow the rules in the game, respecting friends formed by habituating children do not choose choose friends to be there next to him and listen to the instructions of friends in front, a confident character is formed by habituation of children giving instructions in the middle of their own, creatively formed by habituation of children mentioning names of objects or animals to imitate other friends, self-confidence and brave characters formed by habituation children advance in front of the crowd alone.
\end{abstract}

Keywords : Character Education; Traditional Games; Game; Mushroom Game; Early Childhood; 


\section{ABSTRAK}

Pentingnya membentuk karakter yang baik pada anak usia dini dengan stimulasi yang diberikan pada kegiatan permainan tradisional jamuran. Metode yang digunakan dalam penelitian ini adalah metode penelitian kualitatif. Tujuan penelitian ini untuk mendeskripsikan bagaimana permainan tradisional jamuran dapat membentuk karakter anak usia dini. Berdasarkan hasil penelitian permainan tradisional jamuran dapat membentuk karakter pada anak usia dini, yaitu karakter jujur dibentuk dengan pembiasaaan anak tidak bohong ketika di tebak temannya, karakter disiplin dibentuk dengan pembiasaan anak mengikuti aturan yang ada dalam permainan, karakter menghargai teman dibentuk dengan pembiasaan anak tidak memilihmilih teman untuk ada disebelahnya dan mendengarkan instruksi teman yang ada didepan, karakter percaya diri dibentuk dengan pembiasaan anak memberikan instruksi ditengah sendiri, kreatif dibentuk dengan pembiasaan anak menyebutkan nama benda atau hewan untuk ditirukan teman yang lainnya, karakter percaya diri dan pemberani dibentuk dengan pembiasaan anak maju kedepan orang banyak sendirian.

Kata kunci : Pendidikan Karakter; Permainan Tradisional; Permainan; Jamuran; Anak Usia Dini; 


\section{PENDAHULUAN}

Perkembangan zaman dan teknologi semakin pesat, menjadikan dunia seakan-akan tidak berbatas. Tidak berbatas dalam hal nilai-nilai dan budaya. Hal ini yang mempengaruhi pergesaran nilai hidup bangsa Indonesia, kehidupan atau nilai-nilai antar bangsa yang semakin transparan berdampak pada rusaknya karakter bangsa Indonesia. Nilai-nilai luhur bangsa Indonesia sedikit demi sedikit luntur bercampur dengan nilai-nilai yang diadopsi dari kebudayaan barat. Kehidupan warga Negara Indonesia di era milenial cenderung mengikuti gaya kebarat-baratan mulai meninggalkan gaya keindonesia-an. Karakter bangsa seperti, kebersamaan, kesantunan, gotong-royong, telaten, toleransi dan lain-lain mulai luntur dan hilang digantikan dengan kehidupan atau gaya hidup individualisme, materialisme, intoleran, konsumerisme, hedonisme dan budaya instan.

Kondisi Negara Indonesiasaat ini menandakan bahwa ada yang salah pada dunia pendidikan nasional. Pendidikan nasional sedang pada mengalami disorientasi, dikarenakan hegemoni kebudayaan dan gaya hidup barat (asing) dalam dunia pendidikan. Karakteristik bangsa Indonesia semakin jarang dijumpai dalam praktek dunia pendidikan. Keadaan ini sangat mencemaskan, perlu ada upaya khusus untuk menjadikan dunia pendidikan Indonesia berkembang mengikuti perkembangan teknologi tanpa meninggalkan unsur kebudayaan lokal yang sangat beragam(Fauzi:2016). Membangun sumber daya manusia yang berkualitas tidak harus dengan meninggalkan unsur-unsur kebudayaan local, karena pendidikan yang bersumber dari kearifan local akan menjadi pembangunan generasi dengan sumber lokalitas.

Kebudayaan menentukan perkembangan sosial suatu bangsa, oleh karena itu pembentukan karakter hendaknya bersumber dari kebudayaan bangsa itu sendiri. Menjadikan generasi penerus bangsa yang bermutu dan berkarakter dengan tidak menghilangkan kebudayaan local, bahkan menjadikan kebudayaan local sebagai sumber. Akibat dari pendidikan yang tidak bersumber pada kearifan local atau budaya bangsa menjadikan generasi penerus bangsa tidak paham dengan bangsanya sendiri bahkan bisa sampai tidak mengenali bangsanya sendiri. Generasi yang seperti ini akan menjadi orang asing dirumah sendiri, berawal dari keasingan, akan berujung pada ketidak sukaan generasi mendatang dengan kebudayaannya sendiri(Susanti et al., 2014). 
Untuk mengoptimalkan pembentukan generasi yang unggul dan berkarakter kebudayaan Indonesia harus di mulai dari pendidikan anak usia dini, karena pada jenjang pendidikan ini anak sedang dalam masa keemasan, namun metode yang digunakan harus menyesuaikan tingkat perkembangan anak, dan karakteristik anak usia dini sendiri. Dimana pada usia 0-6 tahun dunia anak adalah dunia bermain dan permainan, yang berorientasikan pada kegiatan aktif dan menyenangkan. Kegiatannya pun tidak hanya sampai pada tingkatan menyenangkan tapi juga harus dapat menstimulasi pertumbuhan dan perkembangan anak, dan menggali potensi yang ada pada diri anak, dan juga menumbuhkan karakter bangsa Indonesia. PAUD merupakan lembaga yang tepat untuk tetap memelihara kelangsungan permainan tradisional Indonesia dari gerusan arus teknologi(Wulansari, 2017).

Praktik permainan yang dilakukan oleh anak usia dini mengalami perubahan yang signifikan. Dunia permainan anak saat ini didominasi oleh jenis permainan modern yang menggunakan mesin dan elektronik, yang mana sebagian besar adalah produk impor dan juga yang berbasis online. Sedikit demi sedikit, permainan yang bersumber dari kearifan lokal pudar dan bahkan hampir hilang tergantikan oleh permainan berbasis online. Oleh karena itu permainan tradisional yang didalamnya terdapat unsur nilai-nilai dan kultur bangsa Indonesia harus di revitalisasi agar tidak tertinggal dan dapat bersaing dengan permainan lain yang di dominasi oleh permainan online. Anak-anak zaman sekarang lebih akrab dengan game online, dan game elektronik lainnya dibandingkan dengan permainan tradisional seperti:cublak-cublak suweng, gobak sodor, petak umpet, jamuran, congklak dan lain-lain. Banyak anak memiliki keterampilan sosial yang rendah serta cenderung tidak memiliki teman, cenderung minder dan tertutup(Fitriani \& Maharani, 2019).

Nilai pendidikan dan kebudayaan pada permainan tradisional yang tadinya mampu membentuk anak menjadi manusia yang berkarakter dan berbudaya semakin tidak berdaya karena tergerus oleh berbagai permainan online yang masuk ke Indonesia. Maka dari itu sudah seharusnya permaianan tradisonal mendapatkan perhatian khusus untuk revitalisasi dan rekonstruksi. Dalam hal ini peran lembaga pendidikan sangatlah besar, untuk mengenalkan kepada generasi muda mengenai permainan tradisional dengan menjadikannya salah satu alat pembelajaran dalam dunia pendidikan. Dalam penelitian ini, peneliti mengkaji salah satu jenis permainan 
tradisonal yakni permainan jamuran, yang sudah tidak popular lagi dikalangan generasi muda, sebagai bentuk upaya rekonstruksi permainan tradisional, supaya nilai-nilai yang terkandung didalam permainan jamuran ini dapat ikut serta membangun generasi yang berkarakter(Latifah, Chandra, \& Sagala, 2014).

\section{METODE PENELITIAN}

Metode penelitian pada penelitian ini adalah metode penelitian studi kepustakaan (library research). Studi kepustakaan atau library research dapat diartikan sebagai serangkaian kegiatan yang berkenaan dengan metode pengumpulan data pustaka, membaca dan mencatat serta mengolah bahan penelitian(Zed, 2003). Pada penelitian kepustakaan atau library research harus memperhatikan tahapan langkah dalam meneliti kepustakaan yaitu yang berupa metode dalam membaca, mengumpulkan data dan mengelola bahan pustaka serta mengumpulkan peralatan yang harus dipersiapkan agar memudahkan dalam mendapatkan data.

\section{HASIL DAN PEMBAHASAN}

\section{Pendidikan Karakter Anak Usia Dini}

Karakter merupakan hal mendasar untuk membangun sebuah bangsa, begitupun dengan bangsa Indonesia. Karena karakter merupakan episentrum untuk pembangunan bangsa Indonesia sendiri yang harus dibentuk dan dikembangkan secara baik dan benar. Pendidikan karakter seperti yang sudah di dengungkan oleh pemerintah Negara republik Indonesia di tahun 2010 dengan deklarasinya yaitu pendidikan budaya dan pendidikan karakter merupakan gerakan nasional yang dimulai di januari tahun 2010 hingga saat ini(Emiliyana, 2010). Pendidikan karakter dipercaya akan menjadikan Negara Indonesia lebih baik dimasa depan dengan berbekal generasi yang memiliki karakter yang baik. Membentuk karakter seseorang membutuhkan waktu yang cukup lama, dan hasilnya tidak bisa dilihat secara instant. Maka dari itu sebaiknya pendidikan karakter diberikan pada anak sedini mungkin, pada saat anak dalam masa golden age. Pada masa golden age anak sedang pada jenjang pendidikan anak usia dini, maka lembaga pendidikan anak usia dini memiliki peran yang sangat penting dalam menstimulasi karakter yang baik pada anak. Hasil dari pendidikan karakter baru bisa 
dirasakan saat anak beranjak dewasa dan berbaur dalam masyarkat(Lusiana 2012).

Pendidikan karakter merupakan suatu usaha menanamkan nilainilai kebaikan kepada Tuhan yang maha Esa, diri sendiri, lingkungan dan Negara kesatuan republic Indonesia agar menjadi warga Negara yang memiliki akhlak yang mulia untuk kemajuan bangsa dan agama(Risnawati 2012). Dan lembaga pendidikan anak usia dini merupakan lembaga pendidikan formal yang bertanggung jawab dalam hal pembentukan karakter yang baik bagi anak usia dini. Nilai-nilai yang harus ditanamkan pada anak usia dini memiliki keanekaragaman, seperti nilai ketuhanan yang maha Esa, kejujuran, nilai kedisiplinan, nilai tanggungjawab, saling menghormati, toleransi, kerja keras, cinta damai, kepemimpinan, sportif dan lain-lain.(Yati and Pd 2016) Nilai karakter yang ditanamkan harus bersumber dari agama, pancasila, tujuan pendidikan nasional dan juga kultur budaya masyarakat setempat,supaya jika dewasa nanti di harapkan anak dapat diterima dengan baik di lingkungan masyarakat.

Berdasarkan sumbernya, nilai karakter bisa di identifikasikan menjadi tiga yaitu nilai karakter ketuhanan yang meliputi segala pikiran, perkataan dan perbuatan yang bersumber nilai-nilai ketuhanan/ agamis atau religious. Nilai karakter yang bersumber dari diri sendiri yang terdiri dari bertanggung jawab yang merupakan sikap dan perilaku yang harus dilakukan seseorang berkenaan dengan pelaksanaan tugas dan kewajiban atas Tuhan Yanng Maha Esa, diri sendiri, oranglain, serta lingkungan sekitar. Jujur yang merupakan sikap dan perilaku yang menjadikan seseorang selalu dapat dipercaya dalam semua hal, baik dalam perkataan dan perbuatan. Disiplin yang merupakan sikap dan perilaku patuh dan mengikuti aturan yang ada. Percaya diri yang merupakan sikap dan perilaku percaya pada diri sendiri, tidak malu. Mandiri yang merupakan sikap dan perilaku tidak bergantung pada orang lain, mengerjakan tugsa dan pekerjaannya sendiri. Serta nilai karakter yang bersumber dari masyarakat yang meliputi santun yang merupakan sikap dan perilaku yang halus dan baik, baik dalam perkataan maupun perbuatan. Menghargai prestasi dan karya orang lain dengan cara tidak meremehkan atau merendahkan orang lain, menyadari bahwa setiap orang memiliki kelebihan dan kekurangan. Demokratis yang merupakan sikap dan perilaku yang menggap semua orang memiliki hak yang sama tanpa memandang apapun. Sadar mengenai hak dan kewajiban yang 
dimaksudkan sikap dan perilaku yang mengerti akan hak dan kewajiban diri sendiri dan orang lain. Serta peduli lingkungan yang merupakan sikap dan perilaku menjaga lingkungan dari kerusakan yang disebabkan ulah manusia, rasa kesadaran ingin membantu oranglain yang kesusahan.

Pada dasarnya ada lima macam strategi utama yang dapat digunakan untuk menanamkan pendidikan karakter pada anak yaitu dengan contoh atau keteladanan, pembiasaan kedisiplinan, pembiasaan perilaku tanggung jawab, menciptakan lingkungan yang kondusif, dengan integrasi dan internalisasi. Pertama,keteladanan merupakan hal penting yang harus di laksanakan baik di sekolah maupun di rumah. Jika di sekolah anak dapat melihat figure guru dan teman sebaya, jika di rumah anak dapat melihat keteladanan dari orangtua dan keluarga. Keteladanan ini menjadi suatu hal yang penting karena pendidikan karakter tidak hanya di jelaskan dengan kata-kata atau teori, namun pendidikan karakter lebih kepada sikap yang membutuhkan contoh dan figure dalam hal penanamannya, tanpa contoh atau figure anak tidak bisa optimal dalam hal pengaplikasian atau dalam hal mempraktekan pendidikan karakter yang diajarkan.

Kedua, kedisiplinan merupakan kunci kesuksesan. Banyak orang mendapatkan kesuksesan dengan cara menerapkan kedisiplinan pada diri mereka. Kedisiplinan juga merupakan alat dalam pendidikan karakter. Kedisiplinan yang di aplikasikan secara berulang-ulang dan terus menerus akan menghasilkan karakter yang baik, kebiasaan yang baik pula. Dalam ranah pendidikan anak usia dini kedisiplinan bisa diterapkan pada anak bermain, biasanya sebuah permainan mempunyai aturan, dan hal ini bisa menjadi alat sebagai pengukur kedisiplinan, bisa juga sebagai alat pembiasaan sebelum anak belajar tentang aturan-aturan yang ada di masyarakat.

Ketiga, lingkungan yang kondusif juga merupakan strategi utama yang dapat digunakan untuk menanamkan pendidikan karakter setelah hal keteladanan dan kedisiplinan, karena lingkungan yang kondusif dan mendukung akan sangat mendukung dan akan sangat berperan dalam penanaman karakter bagi anak usia dini. Anak akan lebih mudah dan akan lebih terbiasa dengan karakter baik jika lingkungannya mendukung, karena pada hakikatnya karakter merupakan sikap seseorang kepada diri sendiri maupun kepada oranglain. 
Keempat, pemberian tanggung jawab merupakan strategi utama berikutnya yang dapat digunakan untuk menanamkan pendidikan karakter bagi anak didik, pemberian tugas kepada anak bisa melatih rasa tanggung jawab mereka, diharapkan dengan pemberian tugas anak dapat membedakan mana yang hak dan kewajiban. Dalam ranah pendidikan anak usia dini pemberian tanggung jawab contohnya dengan memberi tugas bergilir kepada siswa untuk memimpin berdo'a atau dalam hal bermain anak berhak bermainan dengan mainan yang dia inginkan, tapi dengan syarat mereka harus bertanggung jawab atas mainan yang mereka mainkan dalam hal merapikan kembali seperti semula. Jika pemberian tannggung jawab ini dilaksanakan atau dipraktekan dengan tepat, maka akan di pastikan anak akan tumbuh menjadi orang yang percaya diri, mandiri dan tanggung jawab.

Kelima, integrasi dan internalisasi merupakan strategi utama terakhir yang dapat digunakan untuk menanamkan pendidikan karakter pada anak. Intergrasi yang memiliki arti pembaharuan dan internalisasi yang diartikan penghayatan. Dalam pendidikan karakter harus diadakan integrasi secara bertahap selaras dengan perkembangan dan pertumbuhan anak, hingga akhirnya anak dapat meng-internalisasikan nilai-nilai yang sudah disampaikan dan sudah dicontohkan oleh guru atau orangtua. Dalam hal internalisasi dibutuhkan kegiatan yang dapat membuat anak selalu mengingat nilainilai yang terkandung di dalam kegiatan tersebut, biasanya anak akan selalu mengingat kegiatan yang menyenangkan dan aktif, oleh karena itu kegiatan pembelajaran dalam ranah pendidikan anak usia dini harus aktif dan menyenangkan agar mempermudah anak un tuk menginternalisasikannya(Wibowo:2013).

Menurut Piaget, tahap perkembangan moral (karakter) mempunyai tiga tahapan, yaitu Premoral yang dimulai pada masa anak belum mengerti dan belum paham mengenai etika, aturan dan moral. Moral realisme, yaitu pada masa ini anak sudah mulai mengenal tentang aturan, etika, norma dan moral dan moral relativisme atau pada masa anak sudah mengerti tentang aturan etika norma dan moral, dan sudah dapat menilai mana yang baik dan mana yang buruk (nalar), tidak tergantung pada aturan(Slamet:2012). Pada tingkatan anak usia dini, anak cenderung pada tahapan perkembangan pertama dan kedua, yakni pada usia antara 4-6 tahun. Oleh karena itu peran lembaga pendidikan anak usia dini sangatlah penting dalam hal menstimulasi perkembangan tersebut, dengan cara dan metode yang 
sesuai dengan tingkat perkembangan anak. Stimulasi yang tepat pada pendidikan karakter akan menjadikan anak tumbuh dewasa dengan karakter yang baik dan berakhlak mulia. Kegiatan dalam rangka menstimulasi perkembangan karakter pada anak usia dini, baru pada tahap pengenalan dan pembiasaan karakter yang baik, yang menggunakan berbagai macam cara, salah satu cara yang dapat digunakan yakni dengan permainan pada proses pembelajaran, yang didalam nya terdapat nilai-nilai yang mampu menstimulasi perkembangan anak tersebut. Permainan tradisional jamuran merupakan salah satu contoh jenis permainan yang dapat membentuk dan mengembangkan karakakter yang baik bagi anak usia dini di umur 5-6 tahun atau TK B.

\section{Sejarah Permainan Jamuran}

Permainan tradisional mengarahkan anak supaya menjadi kuat secara mental dan fisik, sosial emosional, pantang menyerah, bereksperimen, bereksplorasi, dan juga dapat menumbuhkan jiwa kepemimpinan. Semua kegiatan yang dilakukan oleh anak dalam permainan tradisional merupakan bagian penting dan strategis yang dapat membangun potensi yang dimiliki oleh anak secara optimal. Salah satu tujuan bermain memang mencari kesenangan, namun mencari kesenangan bukanlah tujuan satu-satunya, melainkan bermain merupakan suatu kebutuhan yang dibutuhkan oleh anak usia dini. Seluruh tahapan perkembangan pada anak dapat tumbuh dan berkembang dengan sangat baik melalui kegiatan bermain yang benar dan tepat. Namun hasil dari itu semuabaru akan muncul dan dapat dirasakan saat anak beranjak remaja dan dewasa.

Bermain dan permainan bukan aktivitas yang melibatkan sebagian diri anak namun kegiatan bermain dan permainan melibatkan keseluruhan dari diri anak, karena pada saat anak sedang bermain anak akan mempraktekan keterampilan yang dimiliki yang dapat mengarahkan atau menstimulasi perkembangan kognitif anak, perkembangan sosial emosional, perkembangan psikomotorik dan kecerdasan majemuk lainnya yang perlu dilatih dan distimulasi supaya berkembang dengan baik dan menghasilkan hasil yang optimal. Dari bermain anak anak mendapatkan pengalaman yang dapat mengembangkan tingkat kreatifitas anak, baik kreatifitas dalam berfikir juga kreatifitas dalam bersosialisasi. Permainan tradisional bukan sekedar permainan anak biasa, karena didalam nya terdapat banyak manfaat yang sangat berguna sebagai sarana stimulasi dalam 
mengembangkan potensi yang dimiliki anak, misalnya untuk mengembangkan kecerdasan emosional, mengembangkan kecerdasan intelektual, dan mengembangkan daya imajinasi supaya tingkat kreatifitas anak meningkat(Nurhayati 2012).

Permainan tradisional merupakan permainan yang tumbuh dan berkembang di bangsa Indonesia dengan kultur dan budaya masyarakat Indonesia sendiri. Permainan tradisional jamuran masuk kedalam kategori permainan sosial, saat bermain permainan tradisional jamurananak dapat belajar mengenai berkomunikasi, mengembangkan kecakapan sosial anak, permainan ini juga dapat menjadi wadah untuk anak belajar bersosialisasi(Latifah, Chandra, and Sagala 2014). Selain masuk kedalam kategori pemainan sosial permainan tradisional jamuran juga dapat di kategorikan sebagai permainan tradisional yang dapat menjadi alat untuk membentuk karakter baik pada anak usia dini, saat bermain permainan tradisional jamuran anak dapat belajar mengenai menghargai orang lain, disiplin, percaya diri, sabar, dan juga santun. Permainan tradisional jamuran merupakan salah satu permainan tradisional yang lahir dan tumbuh di bumi jawa, permainan ini di mainkan dengan banyak anak, ada lagu khusus yang dinyanyikan untuk mengiringi anak-anak pada saat bermain.

Berikut lirik lagu permainan tradisional jamuran:

Jamuran ya gégéthok

Jamur apa ya gégéthok

Jamur gajih mbejijih sa ara-ara

Siram badhé jamur apa

Jamuran ini merupakan permainan yang dikreasikan oleh seorang pendidik berjiwa demokratis yakni salah satu tokoh sunan walisongo, yaitu sunan Giri. Bukan hanya jamuran saja yang beliau ciptakan, beliau merupakan pendidik yang menjadikan permainan sebagai media pembelajaran. Permainan tradisonal diciptakan sekaligus sebagai alat penyebaran islam pada saat itu, syiar tersebut ada dalam filosofi dari nama permainan tersebut yakni "jamuran” yang asal katanya jamur yang mendapat imbuhan -an. Jamur merupakan tumbuhan yang tumbuh di tempat yang lembab, biasanya jamur hanya diasumsikan sebagai tanaman yang tidak berguna bahkan sebagai 
parasit atau pengganggu, namun ada juga beberapa jenis jamur yang dapat dimanfaatkan oleh manusia bahkan dapat dikonsumsi.

Filosofi yang terkandung dalam permainan ini sama halnya seperti manusia yang bisa bermanfaat untuk manusia lain, namun tidak menutup kemungkinan manusia dapat menjadi parasit atau penggangu manusia lain, bahkan bsia menjadi parasit di tempat yang ditempatinya atau lingkungannya atau orang-orang terdekatnya. Maka kita sebagai manusia sudah seharusnya dapat menebar manfaat untuk orang lain, untuk makhluk lain, seperti tumbuhan hewan. Dan juga sudah seharusnya kita menghindari untuk merugikan oranglain, bahkan lingkungan dan alam. Permainan ini di cipatakan oleh sunan Giri selain untuk kesenangan anak-anak, juga untuk menanamkan nilai-nilai pendidikan dan karakter, seperti ketanggapan gerak dan irama, mematuhi aturan, menghargai oranglain, percaya diri, kebersamaan atau sosialisasi dan mengekspresikan emosi yang ada dalam diri, kerja sama, pantang menyerah, selain hal-hal yang sudah disebutkan tadi, permainan ini juga menjadikan anak lebih akrab satu sama lain, dengan menghilangkan skat kasta atau pemisahlainnya, karena anak-anak sama-sama pada lingkaran bergandengan tangan baik kaya maupun miskin, yang pintar ataupun yang kurang pintar, yang cantik ataupun yang kurang cantik dll. Maka sudah seharusnya permainan tradisional jamuran yang kaya akan nilai-nilai pendidikan dan moral ini dilestarikan dan mendapatkan revitalisasi dan dikemas dalam format yang lebih kreatif dan menjadikan permainan ini menjadi lebih menarik. Dan dunia pendidikan harus mengambil peran dalam hal ini, dengan cara menjadikan permainan jamuran ini sebagai salah satu metode pembelajaran di sekolah(putri fitriani and Hamarani 2019).

3. Langkah-langkah Permainan Jamuran

Biasanya permainan tradisonal jamuran dimainkan oleh anak pedesaan yang berjumlah 10 orang, langkah yang pertama mereka hompimpa untuk menentukan siapa yang ditengah yang bertugas untuk memerintah, setelah mendapatkan satu orang yang kalah, yang lain membuat lingkaran besar dengan tangan bergandengan, yang kalah tadi berada pada tengah lingkaran. Kemudian bersama-sama menyanyikan lagu jamuran dengan bergoyang ke kanan dan kekiri dengan berpegangan tangan. Kemudian bersama-sama menyanyikan lagu jamuran dengan keras dan ceria, Jamuran ya gégéthok,Jamur apa ya gégéthok,Jamur gajih mbejijih sa ara-ara, Sira badhé jamur apa? 
Setelah lirik "sira badhe jamur apa" kemudian yang kalah tadi atau yang ditengah menyebutkan nama benda atau nama hewan anak-anak yang membentuk lingkaran tadi menirukan sesuatu yang disebut oleh anak yang kalah. misalnya "jamur patung" maka yang lain harus bergaya menyerupai patung, tidak boleh bergerak tidak boleh berkedip, contoh lain "jamur kucing" maka yg membuat lingkaran tadi berpura-pura menjadi kucing.

Kemudian anak yang ditengah yang memerintah tadi memilih salah satu anak yang salah atau tidak tepat dengan arahan dia, misalnya pada saat anak yang ditengah mengatakan "jamur patung"yang artinya anak yang lain harus diam tidak bergerak dan tidak tersenyum namun ada salah satu anak yang tersenyum atau tertawa maka anak yang ditengah tadi menunjuk anak yang dianggap gagal saat menjadi patung, dan anak yang tersenyum atau bergerak dan tertawa tadi dianggap kalah dan menggantikan anak yang ada ditengah. barangsiapa yang tersenyum, atau bergerak maka dia yang akan menggantikan anak yang ditengah tadi. Kemudian diulang lagi dari awal dengan menyanyikan lagu jamuran lagi. Lirik lagu permainan jamuran juga merupakan salah satu bentuk budaya yang cocok dijadikan alat pembelajaran bagi anak usia dini. Lagu dolanan seperti lagu jamuran juga mengandung ajaran moral sebagai alat untuk membentuk karakter anak yang baik. Lingkungan masyarakt juga memiliki peran penting dalam membentuk tersebut. Jika di manfaatkan secara benar dan baik maka permainan sangat mungkin memberikan pengaruh positif pada anak. Sepintas lirik lagu dolanan hanya berupa nada-nada, namun jika diamati lebih dalam lirik lagu dolanan termasuk lagu jamuran memiliki banyak makna yang dapat menjadi sarana dan alat untuk membentuk karakter anak usia dini. Berikut ini merupakan unsur positif dari penggunaan permainan untuk menstimulasi anak usia dini: a) Menghilangkan keseriusan yang menghambat, b) Menyingkirkan stress, c) Menjadikan lebih kreatif, d) Melibatkan banyak anak, e) Menjadikan pengalaman sebagai makna belajar, f) Menjadikan anak didik sebagai sumber belajar, g) Meningkatkan proses belajar, h) Mencapai tujuan dengan kesenangan. 
Sebuah permainan harus memiliki keterkaitan dengan proses pembelajaran supaya menjadikan efektif dan menghasilkan hasil yang optimal, permainan harus dapat memberikan kebebasan pada siswa untuk kerjasama dan berkreasi, permainan yang digunakan juga harus menarik dan menantang namun juga jangan sampai menjadikan siswa kecewa dan kehilangan akal, permainan juga harus menyediakan waktu untuk anak merenung, berdialog memberi umpan balik dan berinteraksi dengan siswa. Hal-hal yang telah disebutkan tadi merupakan hal-hal yang harus diperhatikan dalam memilih permainan yang akan digunakan untuk media pembelajaran. Lagu dolanan merupakan salah satu seni budaya yang sangat dekat dengan kehidupan masyarakat, namun peminatnya semakin berkurang. Dikarenakan banyak kesenian modern dengan menggunakan teknologi canggih dan lebih mengghibur yang menjadi pilihan anak-anak. Permainan tradisional juga sering dianggap kuno (ketinggalan zaman). Selain itu permainan yang kurang menarik dalam hal pengemasan dan proses sosialisasi yang kurang oleh generasi sebelumnya. Oleh Karena itu peran lembaga pendidikan sangat berpengaruh dalam pengemasan dan sosialisasi supaya generasi muda dapat mengenal dan mencintai permainan yang bersumber dari kebudayaan masyarakat, yang mempunyai nilai-nilai luhur yang dapat membentuk karakter anak.

4. Nilai-nilai yang terkandung dalam permainan Jamuran

Ada beberapa nilai pendidikan karakter yang terkandung dalam permainan jamuran, yang mana nilai itu sangat penting untuk dibiasakan pada anak usia dini. Berikut ini beberapa nilai yang terkandung dalam permainan jamuran diantaranya adalah menghargai teman, karakter ini sebagai dasar dari toleransi, menumbuhkan rasa toleransi dengan membiasakan anak untuk menghargai orang lain. Percaya diri, karakter percaya diri sangat perlu dibiasakan, karena tanpa rasa percaya diri anak menjadi penakut dan pemalu dalam mengerjakan segala hal, pembiasaan karakter ini sangat penting untuk anak dimasa depan. Kemandirian, karakter kemandirian yang membiasakan anak mengerjakan sesuatu sendiri tanpa bantuan oranglain, mengandalkan diri sendiri dan tidak mengandalkan 
oranglain, rasa kemandirian akan muncul beriringan dengan karate percaya diri, karakter kemandirian juga sangat penting untuk perkembangan dan pertumbuhan anak ditahap selanjutnya. Jujur, merupakan karakter yang dibiasakan dalam permainan jamuran, karakter jujur dengan mengakui kekalahan dan kemudian menerima hukuman adalah point yang di fokuskan dalam permainan jamuran. Kreativitas, merupakan hal yang difokuskan pada permainan jamuran, menjadikan anak berfikir luas. Disiplin, merupakan hal yang penting dan harus dibiasakan pada anak usia dini, mengikuti aturan permainan merupakan bentuk usaha dalam membiasakan anak untuk disiplin, disiplin merupakan salah satu kunci kesuksesan yang penting dan harus dibiasakan sedini mungkin pada anak.

\section{Pembentukan Karakter Anak Melalui Permainan Jamuran}

Permainan jamuran diawali dengan hompimpa untuk menentukan yang kalah, yang akan berada ditengah, anak yang kalah harus mengakui kekalahannya dan menerima hukuman sesuai dengan aturan permainan, hal ini sebagai bentuk pembiasaan anak terhadap karakter jujur, percaya diri dan pemberani. Kemudian anak yang lain membentuk lingkaran dengan bergandengan tangan menyanyikan lagu jamuran dengan keras dan ceria sambil bergoyang kekanan dan kekiri, dan memperhatikan anak yang berada ditengah yang akan menyebutkan nama jamur yang harus ditiru, kegiatan ini sebagai bentuk pembiasaan anak dalam menghargai teman, dan disiplin menaati aturan permainan. Saat nyanyian sudah pada lirik "sira badhe njaluk jamur opo?" anak-anak yang membuat lingakaran berhenti bergoyang dan memperhatikan anak yang ada ditengah, ini adalah waktunya anak yang ada ditengah menyebutkan nama benda atau hewana yang dia inginkan untuk ditiru oleh teman-temannya, kegiatan ini mebiasakan anak-anak yang ada dilingkaran untuk disiplin mengikuti aturan saat waktunya berhenti bergoyang anak harus berhenti, disini lah pembiasaan disiplin diterapkan, sedangkan untuk anak yang berada ditengah dibiasakan juga disiplin dan kreatif, disiplin saat waktunya menyebutkan nama jamur apa yang dia mau dia harus menyebutkannya, bukan disaat anak-anak yang lain masih bernyanyi, 
berfikir kreatif juga dibiasakan pada kegiatan ini karena anak diharuskan berfikir cepat dan unik dengan waktu yang terbatas yaitu pada saat menyebutkan nama jamur yang dia mau. Hal tersebut juga termasuk pembiasaan untuk percaya diri, karena anak yang percaya dirinya kurang akan merasa malu.

Kemudian setelah anak yang ditengah menyebutkan apa yang dia mau, anak yang membuat lingakaran akan menirukan apa yang dikatakan anak yang ditengah, kegiatan ini termasuk pembiasaan kedisiplinan mengikuti aturan dalam permainan, juga termasuk pembiasaan kepada anak supaya anak kreatif, kreatif dalam hal menirukan sesuatu. Pada saat anak-anak yang melingkar menirukan apa yang anak ditengah mau, anak yang ditengah mengamati temannya dan menentukan mana yang tidak sesuai dengan apa yang dikatakannya, anak yang ditengah harus memilih dengan bijak, hal ini juga termasuk pembiasaan untuk anak. Sedangkan untuk anak yang telah dianggap salah, dia harus mengakui bahwa dirinya salah, dan menerima hukumannya yakni dengan menggantikan anak yang ditengah tadi, kegiatan ini membiasakan anak untuk jujur, dan menghargai teman, serta percaya diri dan pemberani. Jika tidak ditemukan yang salah maka permainan dilanjutkan dengan menyanyi dan berputar lagi, kemudian menanyakan lagi "sira badhe njaluk jamur opo?" sampai ada yang kalah dan menggantikan di tengah. Yang telah dijelaskan diatas merupakan pembiasaan karakter pada setiap gerak dan kegiatan yang ada di permainan tradisional jamuran. 


\section{KESIMPULAN}

Dalam permainan tradisional jamuran anak dapat mempraktekan beberapa nilai kehidupan yang sudah di jelaskan oleh pendidik (guru) didalam kelas, misalnya anak membiasakan diri dengan jujur, percaya diri, menghargai oranglain, taat kepada aturan, bijaksana dalam memilih dan menentukan sesuatu, dan juga kreatifitas. Dalam permainan jamuran ini anak tidak hanya mendapat teori namun anak-anak langsung praktek dan diharapkan anak akan terbiasa melakukan hal-hal tersebut dan melekat menjadi karakter yang baik bagi anak, dan pembiasaan yang paling menonjol pada permainan jamuran adalah pembiasaan percaya diri atau pemberani, menghargai teman, dan kreatif. 


\section{DAFTAR PUSTAKA}

Emiliyana, D. M. (2010). Peranan Permainan Tradisional Gobag Sodor Dalam Pengembangan Aspek Motorik dan Kognitif Anak TK Pilangsari I Gesi Sragen.

Fitriani, A. P., \& Maharani, P. A. (2019). Peningkatkan Kemampuan Sosial Anak Melalui Permainan Jamuran. Jurnal Pendidikan Modern, 4, 37-43. Retrieved from http://ejournal.stkipmodernngawi.ac.id/index.php/jpm/article/v iew $/ 71$

HAPIDIN, H, Y YENINA - Jurnal Pendidikan Usia Dini, and undefined 2016. neliti.com PENGEMBANGAN MODEL PERMAINAN TRADISIONAL DALAM MEMBANGUN KARAKTER ANAK USIA DINI. https://www.neliti.com/publications/118039/pengembanganmodel-permainan-tradisional-dalam-membangun-karakter-anakusia-dini (March 26, 2020).

Latifah, U., Chandra, A., \& Sagala, D. (2014). Upaya Meningkatkan Interaksi Sosial Melalui Permainan Tradisional Jamuran Pada Anak Kelompok B Tk Kuncup Sari Semarang Tahun Pelajaran 2014/2015. Journal.upgris.ac.id. Retrieved from http://journal.upgris.ac.id/index.php/paudia/article/view/515 Nurhayati, Iis. 2012. "Peran Permainan Tradisional Dalam

Pembelajaran Anak Usia Dini (Studi Di PAUD Geger Sunten, Desa Suntenjaya).” e-journal.stkipsiliwangi.ac.id 1(2). http://ejournal.stkipsiliwangi.ac.id/index.php/empowerment/article/vie w/614 (March 28, 2020).

Risnawati, Vivit. 2012. "Optimalisasi Pendidikan Karakter Anak Usia Dini Melalui Sentra Main Peran Taman Kanak-Kanak Padang." ejournal.unp.ac.id $1(1)$.

http://ejournal.unp.ac.id/index.php/paud/article/view/1595

(March 13, 2020).

Susanti, I. S., Lutfi, A., Kimia, J., Matematika, F., Ilmu, D., \& Alam, P. 
(2014). Pengembangan Permainan Tradisional Jamuran Sebagai Media Pembelajaran Tata Nama Senyawa di Kelas X SMA. In Unesa Journal of Chemical Education (Vol. 3). Retrieved from https://jurnalmahasiswa.unesa.ac.id/index.php/journal-ofchemical-education/article/view/8242

Wulansari, B. Y. (2017). Pelestarian Seni Budaya dan Permainan Tradisional Melalui Tema Kearifan Lokal Dalam Kurikulum Pendidikan Anak Usia Dini. Jurnal Ilmiah Pendidikan PraSekolah Dan Sekolah Awal, 1-11. Retrieved from http://journal.umpo.ac.id/index.php/indria/index

Yati, Patmi, and S Pd. 2016. XVIII journal.iain-samarinda.ac.id PENDIDIKAN KARAKTER ANAK USIA DINI MELALUI METODE PEMBELAJARAN FIELD TRIP. https://journal.iainsamarinda.ac.id/index.php/lentera_journal/article/view/578 (March 13, 2020)

Zed, M. (2003). Metode Peneletian Kepustakaan. 